\title{
An Investigation on the Cooling System of Synchronous Motor for Electric Buses
}

\section{Elektrikli Otobüsler için Senkron Motoru Soğutma Sistemi Üzerine Bir Araştırma}

\author{
Mohammad Bashjaweesh ${ }^{(}{ }^{(}$, Omran Mansour ${ }^{1}$, Gamze Gediz Ilis ${ }^{2}{ }^{*}$ \\ ${ }^{1}$ Istanbul Okan University, Mechanical Engineering Department, Tuzla, Istanbul, Turkey \\ ${ }^{2}$ Gebze Technical University, Mechanical Engineering Department, Kocaeli, Gebze, Turkey \\ Sorumlu Yazar / Corresponding Author*: ggedizilis@gmail.com, ggediz@gtu.edu.tr \\ Geliş Tarihi /Received: 10.08 .2020 \\ Araștırma Makalesi/Research Article \\ Kabul Tarihi / Accepted: 20.12.2020 \\ DOI:10.21205/deufmd.2021236819 \\ Atıfșekli/How to cite: BASHJAWEESHM., MANSOUR O., ILIŞ G.G.(2021). An Investigation on the Cooling System of Synchronous Motor for Electric \\ Buses. DEÜFMD 23(68), 567-573.
}

\begin{abstract}
Due to the increase of the electric vehicle market, the mileage of the electric vehicle with full battery gets importance. The ambient temperature or the abuse driving conditions directly affects the mileage of the electric vehicle. To increase the mileage, the analysis of the thermal management system of the electric vehicle should be studied well. Besides the battery, one of the most important components of an electric vehicle is the synchronous motor. Thus, this study focused on the cooling methodology of permanent magnet synchronous motor which is limited in the literature. The cooling methodology of the synchronous motor directly affects battery performance. To analyze the thermal management system of an electric vehicle, analyzing the synchronous motor cooling water circulation methodology is taken into account and numerical simulations are validated by experimental results with $0.2 \%$ error. The effect of the mass flow rate of the motor coolant on the pressure drop is also analyzed. Keywords: Synchronous Motor, Cooling System, Electric Vehicle, Liquid Cooling, Permanent Magnet Electrical Machines
\end{abstract}

Öz

Elektrikli araçların satışının artması nedeni ile bu araçların tam dolu batarya ile kat edebildikleri yolun uzunluğu giderek özem kazanmaya başlamıştır. Hava sıcaklı̆̆ı veya zorlu sürüş durumları elektrikli araçların kat edebildikleri mesafeyi doğrudan etkilemektedir. Kat edebildikleri mesafeyi arttırabilmek için elektrikli araçların termal yönetim sistemlerinin çok iyi şekilde analiz edilmesi gerekmektedir. Bataryanın yanında senkron motor elektrikli araçların en önemli komponentlerinden biridir. Dolayısı ile bu çalışma, sabit mıknatıslı bir senkron motorun literatürde de çok az ele alınan soğutma metoduna odaklanmıștır. Senkron motorun soğutma metodu doğrudan bataryanın performansı ile ilgilidir. Elektrikli araçların termal yönetim sistemini analiz edebilmek için senkron motorun soğutma suyu sirkülasyonu metodu ele alınmış ve sayısal sonuçlar deneysel sonuçlar ile $0.2 \%$ hata payı ile doğrulanmıştır. Motor soğutma suyunun debisinin, basınç düşüşüne etkisi de ayrıca incelenmiștir. 


\section{Introduction}

International Energy Agency indicates that in their report in 2017 that the use of electric vehicles and hybrid vehicles raised to 1200 thousand and 800 thousand, respectively in 2016. In Europe, $80 \%$ of the available amount of buses will be converted to electric vehicles by 2025 [1]. The importance and the use of electrical vehicles show an increase due to the coming shortage of fossil fuels and their negative effect on the environment. It is known that the increase in temperature of the motors and batteries of electrical or hybrid vehicles reduces the performance of these vehicles. Due to this reason, researchers are focusing on the performance improvement of these vehicles by eliminating this handicap. As shown in Figure 1, electric vehicles have three main components in their thermal systems; a battery, a motor, and an HVAC system working both for passenger comfort and cooling down the battery.

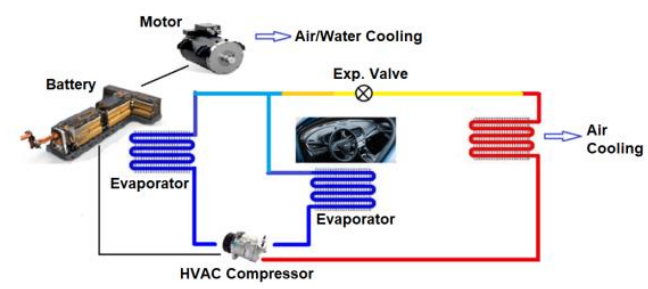

Figure 1. The HVAC cooling cycle of an electric vehicle

There are many types of research available in literature dealing with the cooling/heating system of the battery due to keeping the Li-ion battery operation at $15-35^{\circ} \mathrm{C}[2,3]$. Due to that reason, many studies have been performed to adopting active and passive methods such as liquid, air cooling, and phase change cooling to dissipate heat from the battery pack [4-6].

On the other hand, the thermal analysis of the motor directly affects the performance of the vehicle. Due to hard torque needed conditions such as climbing the ramps or abuse low/high ambient temperatures, the motor needs more power. These factors will cause a higher both motor and battery temperature rise, which will demagnetize the motor and reduce the motor/battery efficiency [7]. The high temperature can cause the failure of insulation materials, the life of the motor [8]. As seen, the cooling of the motor is so important and many researchers are working on this topic. The cooling of a motor can be divided into two categories such as air-cooling (mainly dissipates heat by fins on the surface of the casing) $[9,10]$, and liquid-cooling $[11,12]$.

The improvement of the material for thermal performance increase, the effect of the cooling system on the performance of the motor, and the effect of the torque on the temperature distribution of a motor are the studies for the motor cooling system in the literature. On the other hand, studies dealing with the cooling fluid on the effect of the cooling strategy of the synchronous motor is limited. Mutlu [13] has taken into consideration the electrical caused losses and study on a high-efficiency liquid cooling system by using CFD analysis in order to study the effectiveness of the design. In the study of Rehman and Seong [14], a threedimensional steady-state numerical method is used to investigate the performance of a cooling jacket using water as the primary coolant of a three-phase induction motor. Polikarpova [15] performed many simulations on the cooling methodology of synchronous motors and discussed the direct and indirect cooling systems of the motors in detail considering the geometrical factor of the motor. Satrústegui et al. [16] studied on thermal modeling of an water cooled motor. The cooling system of the motor is taken into account and the distance between cooling ducts and the distance between the ducts and the stator stack have found as most significant parameters. The paper of Zhang et al. [17] studied on thermal analysis of fault-tolerant multisector machine. It is found that the machine can produce torque for 10 minutes before the winding temperature exceeds the limitation. To investigate the potential and effectiveness of direct oil cooling of a permanent synchronous motor, Ponomarev et al. [18] built the lumped parameters thermal network. The temperature distribution is plotted in their study. The optimum volumetric coolant flow is discussed for the motor in their study. There are various methods for removing heat from electric motors and the most common cooling methods in the electric engine are air and cooling systems. Due to friction, heat generation occurs and for that reason, water-cooled electric engines are developed [19]. The refrigerant of a watercooled engine is cooled by an air radiator. In the 
winter season, refrigerant can be cooled without a problem but, in the summer season or abuse road conditions such as climbing the hill needed conditions, refrigerant cannot be cooled properly by air radiator. This is a major problem encountered in the water-cooled engine causing insufficient cooling in the electric engine.

As known, an electrical machine converts electrical energy into mechanical energy, and vice versa. Permanent magnet electrical machines are considered as more efficient alternatives of induction motors, as the rotor winding Joule losses of the former are eliminated due to the utilization of permanent magnets as the rotor field source [20]. The permanent magnet synchronous motor (PMSM) was made to replace the induction motors since induction motors are less efficient than the PMSM.

A PMSM uses permanent magnets embedded inside the steel rotor to create a constant magnetic field. The stator carries windings connected to an AC supply to produce a rotating magnetic field. At synchronous speed, the rotor poles lock to the rotating magnetic field. In this study, a TM4/SUMO HD type 336kg LSM280 type PMSM is analyzed (Figure 2). This PMSM delivers $250 \mathrm{~kW}$ peak, $170 \mathrm{~kW}$ continuous power with a peak efficiency of $95 \%$.
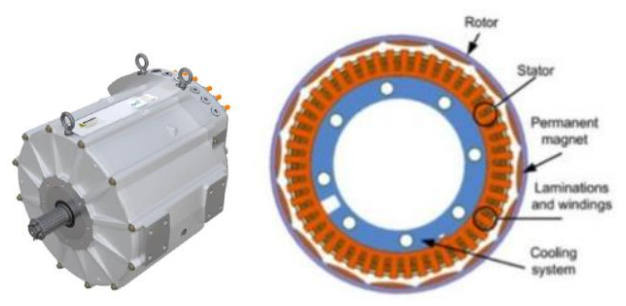

Figure 2. The PMSM by TM4/SUMO HD, type LSM280.

As shown in Figure 2, the cooling system is inside of the motor and shown in blue color. The cooling water is circulated inside of the pipe which is illustrated in Figure 3.

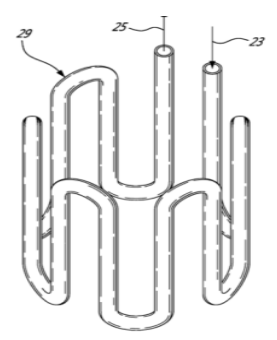

Figure 3. Cooling pipes for the considered PMSM [18].

This study aims to analyze and model the cooling system of PMSM of an electric vehicle. The CFD analysis was performed for the pipe which is responsible for the cooling process of the synchronous motor. The results are compared with the experimental results and a good comparison is found. The developed model can be used in order to improve the cooling performance of the synchronous motor and the real-time conditions can be estimated by using the developed model.

\section{Numerical Analysis for the Cooling System of Synchronous Motor}

The design of the cooling pipes, the materials of these pipes, diameters etc. are found by using the patent of this PMSM as mentioned in Figure 3 [21]. Based on the information which is given by this patent, the model is developed and the cooling pipes of the considered synchronous motor are illustrated in Figure 4. The pipe is made of aluminum. The cooling system contains 12 straight pipes and 11 U-bent pipes, the simulation was conducted using a fine tetrahedral mesh with the following number of nodes and elements, 200730 and 870357, respectively. 


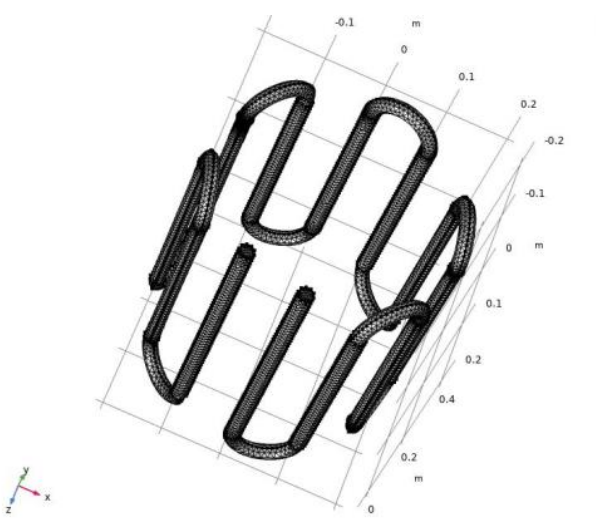

Figure 4. Model 12 passes pipe arrangement of the synchronous motor cooling system with tetrahedral mesh.

The thermo-physical properties of the water and the tube and the necessary conditions are given in Table 1.

Table 1. Thermo-physical properties of the water and the tube and the necessary conditions.

\begin{tabular}{|c|c|c|}
\hline Parameter & Symbol & Value \\
\hline $\begin{array}{l}\text { Water } \\
\text { density } \\
\left(\mathrm{kg} / \mathrm{m}^{3}\right)\end{array}$ & $\rho$ & 998 \\
\hline $\begin{array}{l}\text { Water inlet } \\
\text { velocity } \\
(\mathrm{m} / \mathrm{s})\end{array}$ & $v$ & 0.775 \\
\hline $\begin{array}{l}\text { Water } \\
\text { viscosity } @ \\
\text { average } \\
\text { temperature } \\
\left(\mathrm{N} / \mathrm{m}^{2} \mathrm{~s}\right)\end{array}$ & $\mu$ & $5.47 \times 10^{-4}$ \\
\hline $\begin{array}{c}\text { Ave. Specific } \\
\text { Heat of the } \\
\text { water } \\
(\mathrm{J} / \mathrm{kgK})\end{array}$ & $\mathrm{Cp}$ & 4.181 \\
\hline Pr Number & $\mathrm{Pr}$ & 2.534 \\
\hline $\begin{array}{l}\text { Mass flow } \\
\text { rate of the } \\
\text { water }(\mathrm{kg} / \mathrm{s})\end{array}$ & $\dot{m}$ & 0.336 \\
\hline
\end{tabular}

By considering the dimensions of the motor, the pipe`s length is found to be $6.1 \mathrm{~m}$ and a diameter of 1 inch with a thickness of $1 \mathrm{~mm}$. The numerical analysis has been considered as an internal flow problem and a symmetry axis is considered from the center of the pipe. The flow rate is taken from
- the manufacturer's experimental results and a flow rate of $1200 \mathrm{~L}$ /hour was chosen. The following assumptions are considered for the numerical simulations:

1)Tube wall conduction resistance is considered as negligible

2) The liquid is considered as incompressible liquid and viscous dissipation is neglected.

3)Thermo-physical properties of the materials are taken as constant.

4) $\mathrm{k}-\omega$ model is considered as turbulent model which is useful in many cases such as internal flows, flows that exhibit strong curvature, separated flows, and flow through a pipe bend.

\section{Results}

\subsection{Numerical Results}

The cooling pipes of the synchronous motor are numerically simulated by using ANSYS-Fluent. Firstly, the boundary conditions are defined for the model. The average surface temperature of the motor and the average inlet temperature of the water is taken as 324 and $323 \mathrm{~K}$, respectively. The inlet water velocity is taken as $0.775 \mathrm{~m} / \mathrm{s}$ as given in the experiments. The turbulent model is chosen as k-omega/SST which is a suitable model for turbulent flow through pipes. Gravitational effects are considered during numerical solutions. The velocity and pressure distributions of the pipe are illustrated in Figure 5. 
DEÜ FMD 23(68), 567-573, 2021

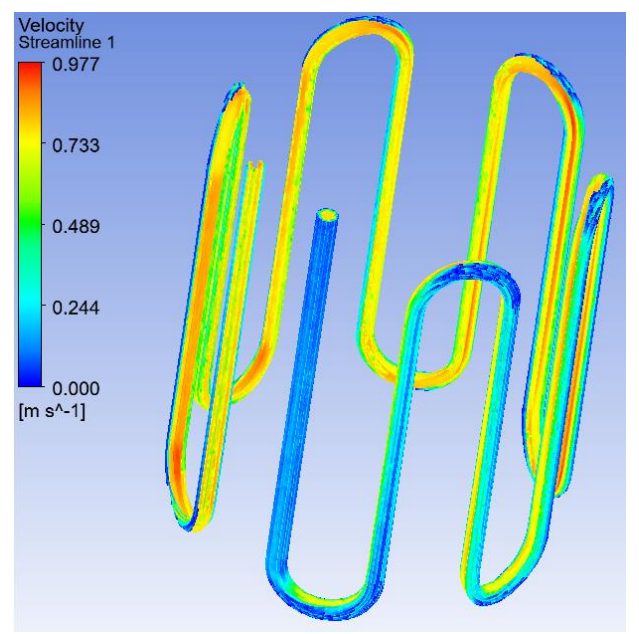

(a)

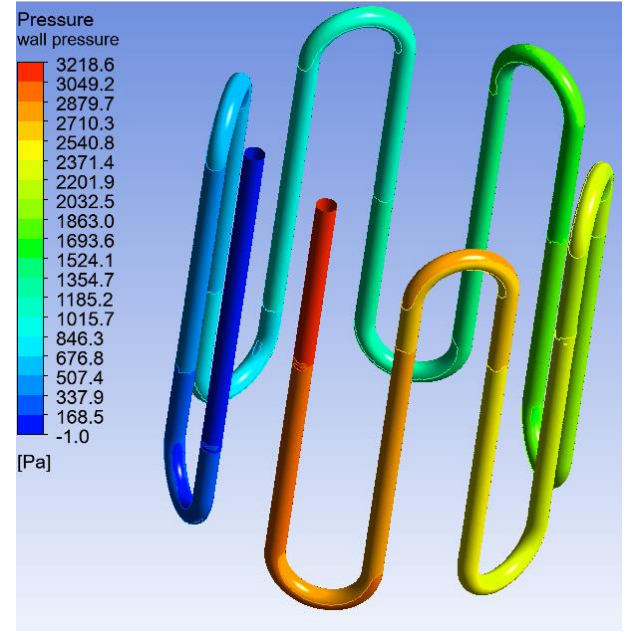

(b)

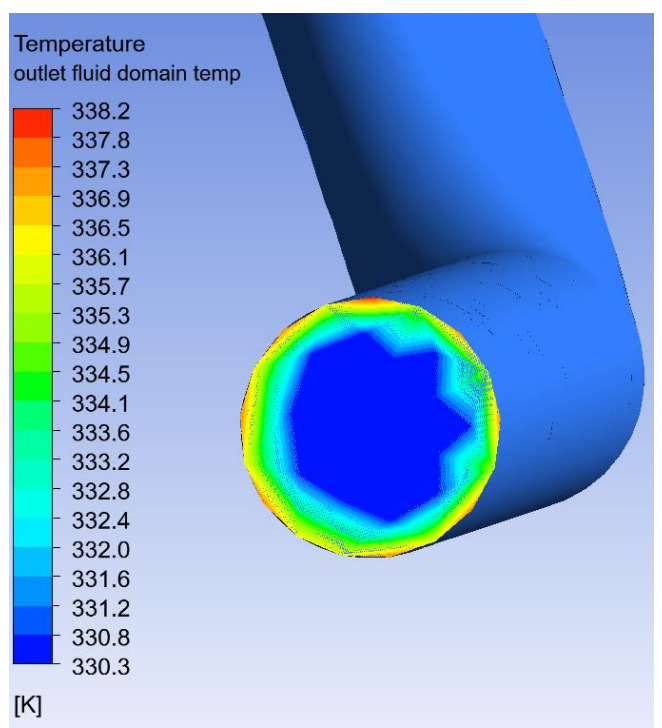

(a)

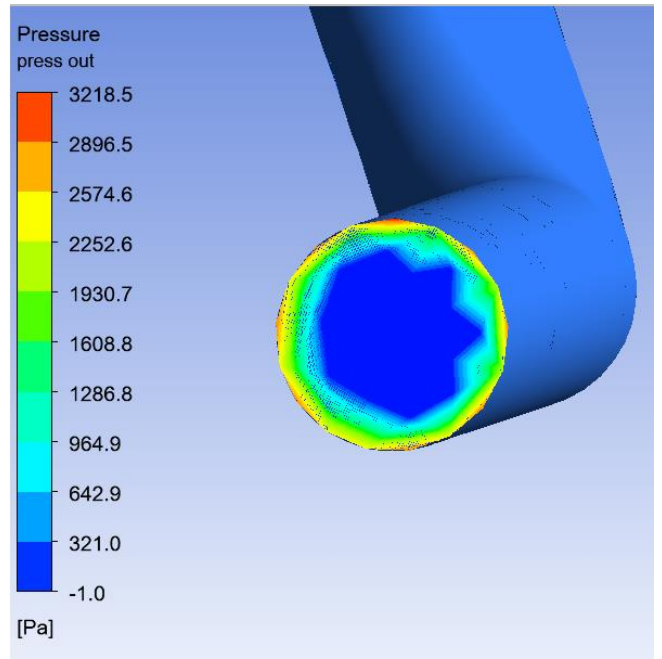

(b)

Figure 6. The distribution of the water outlet, a) temperature, b) pressure.

on the boundary conditions, the pipe outlet temperature and pressure are also given in Figure 6. As seen, the average outlet temperature is found as $328.95 \mathrm{~K}$ and the average pressure drop is $1.58 \mathrm{kPa}$.

\subsection{Comparison of Numerical Results with Experimental Results}

In this section, the numerical results are compared with the experimental data. As seen from Figure 7, the experimental data is given for a real motor experiment. As shown, the experimentally found water inlet/outlet temperature while it is climbing a ramp is plotted on this figure. The surface temperature 
DEÜ FMD 23(68), 567-573, 2021

of the motor is also plotted. As seen, the average value of the water inlet temperature is taken $323 \mathrm{~K}$ and the average surface temperature of the motor is taken $324 \mathrm{~K}$ and used as a boundary condition in numerical simulations. As seen in Table 2, the numerical results are given as a comparison with the experimental average values with errors. The average values of the experimental results given in Fig. 7 are taken and the simulations are performed based on these values. As seen, numerical simulations are in good correlation with the experimental results.

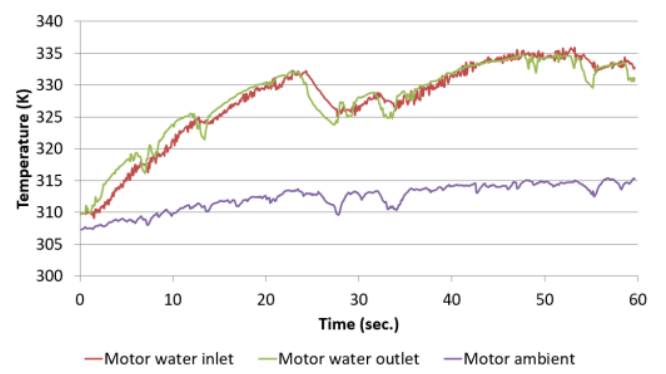

Figure 7. The experimental values.

Table 2. The comparison of the average motor water outlet temperature numerical value with the experimental value.

\begin{tabular}{lc}
\hline \multicolumn{1}{c}{ Parameter } & Value (K) \\
\hline $\begin{array}{l}\text { Average Motor Water } \\
\text { Outlet Temperature - } \\
\text { Experimental }\end{array}$ & 329.75 \\
$\begin{array}{l}\text { Average Motor Water } \\
\text { Outlet Temperature - } \\
\text { Numerical }\end{array}$ & 328.95 \\
Error (\%) & 0.2 \\
\hline
\end{tabular}

As known, the coolant of the PMSM is cooled by the radiator of the vehicle. After leaving the radiator, the coolant first enters the inverter, and after cooling it, passes to the synchronous motor. Due to that reason, affecting the inlet temperature of the motor coolant fluid is directly related to the outlet of the coolant. So, the effect of the mass flow rate of the coolant on pressure drop can be analyzed. Figure 8 shows the effect of the inlet mass flow rate change on the pressure drop. As seen from the figure, the increase in mass flow rate causes increases pressure drops. The increase of the motor torque while driving causes the average temperature increase of the motor surface. Due to that reason, instead of the increase of the coolant mass flow rate, the motor should be cooled by another method such as cooling from the surface.

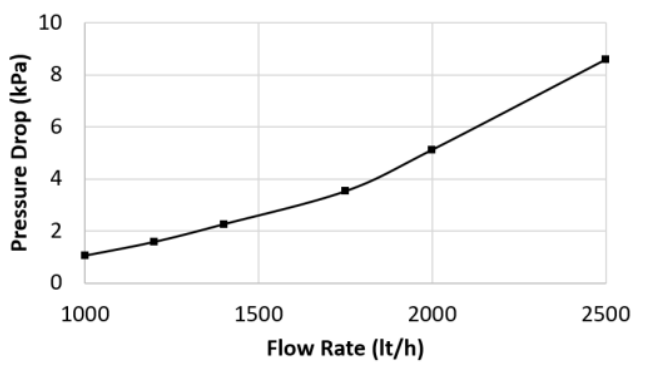

Figure 8. Pressure drop with a change of flow rate of the coolant.

\section{Conclusion}

Due to the increase of electric vehicle usage and the demand of the market, the thermal management systems of the electric vehicles get importance. Besides the battery thermal management, the synchronous motor thermal management is one of the most important points that should be handled thus affects the battery cooling system directly. Unfortunately, the studies on the cooling system of the synchronous motor are limited. In this study, the cooling water circulation is numerically validated with the experimental results. As seen from the results, numerical data have only $0.2 \%$ error with the experimental results. The inlet mass flow rate change on the pressure drop is also analyzed. The increase in the mass flow rate of the coolant causes more pressure drop. Due to that reason, the mass flow rate should be kept at low values which means more cooling load could be necessary for high torques or abuse ambient and road conditions. This study will lead the future studies for the whole thermal management system of electric vehicles with the help of simulating the cooling water circulation of the synchronous motor. 


\section{DEÜ FMD 23(68), 567-573, 2021}

\section{Acknowledgment}

The authors would like to thank TEMSA Co. and Assoc. Prof. Dr. Saban Ünal for their support on the study and sharing the experimental results of the synchronous motor cooling cycle temperature values.

\section{References}

[1] International Energy Agency, IEA. 2017. “Global EV Outlook 2017 Together Secure Sustainable Global EV Outlook 2017." IEA Pub, 1-71. doi:10.1787/9789264278882-en

[2] A. Pesaran, M. Keyser, G.H. Kim, S. Santhanagopalan, K. Smith, Tools for Designing Thermal Management of Batteries in Electric Drive Vehicles (Presentation) National Renewable Energy Lab. (NREL), Golden, CO (United States), 2013, doi:10.2172/1064502.

[3] W. Wu, S. Wang, W. Wu, K. Chen, S. Hong, Y. Lai, A critical review of battery thermal performance and liquid based battery thermal management, Energy Convers. Manag. $182 \quad$ (2019) 262-281, doi:10.1016/j.enconman.2018.12.051.

[4] Y. Wang, Q. Gao, G. Wang, P. Lu, M. Zhao, W. Bao, A review on research status and key technologies of battery thermal management and its enhanced safety, Int. J. Energy Res. 42 (2018) 4008-4033, doi:10.1002/er.4158.

[5] L. Ianniciello, P.H. Biwolé, P. Achard, Electric vehicles batteries thermal management systems employing phase change materials, J. Power Sources 378 (2018) 383-403, doi:10.1016/j.jpowsour.2017.12.071.

[6] A.A.H. Akinlabi, D. Solyali, Configuration, design, and optimization of air-cooled battery thermal management system for electric vehicles: A review, Renew. Sustain. Energy Rev. 125 (2020) 109815 doi:10.1016/j.rser.2020.109815.

[7] R. Wang, Y. Wang, C. Feng, X. Zhang, Powertrain preheating system of tracked hybrid electric vehicle in cold weather, Appl. Therm. Eng. 91 (2015) 252258.

[8] H. He, N. Zhou, C. Sun, Efficiency decrease estimation of a permanent magnet synchronous machine with demagnetization faults, Energy Proc. 105 (2017) 2718-2724.

[9] M. Grabowski, K. Urbaniec, J. Wernik, K.J. Wołosz Numerical simulation and experimental verification of heat transfer from a finned housing of an electric motor, Energy Convers. Manage. 125 (2016) 91-96.

[10] A.S. Fawzal, R.M. Cirstea, T.J. Woolmer, M. Dickison, M. Blundell, K.N. Gyftakis, Air inlet/outlet arrangement for rotor cooling application of axial flux PM machines, Appl. Therm. Eng. 130 (2018) 1520-1529.

[11] K. Li, J. Yan, H. Chen, Q. Wang, Water cooling based strategy for lithium ion battery pack dynamic cycling for thermal management system, Appl. Therm. Eng. 132 (2018) 575-585.

[12] P. Zheng, R. Liu, P. Thelin, E. Nordlund, C. Sadarangani, Research on the cooling system of a 4QT prototype machine used for HEV, IEEE Trans. Energy Convers. 23 (2008) 61-67.

[13] Mutlu Y., Master Thesis. 2011. Elektrikli Arac Motorunun Soğutma Sistem Tasarımı, Master Thesis, Istanbul Technical University
[14] Rehman Z., Seong K. 2018. Three-D Numerical Thermal analysis of Electric Motor and with Cooling Jacket, Energies, 2018, 11, 92

[15] Polikarpova M., Ph.D. Thesis. 2014. Liquid Cooling Solutions for Rotating Permanent Magnet Synchronous Machines, Lappeenranta University of Technology

[16] Satrústegui M., Martinez-Iturralde M., Ramos J.C., Gonzalez P., Astarbe G., Elosegui I. Design criteria for water cooled systems of induction machines, Applied Thermal Engineering 114 (2017) 1018-1028

[17] Zhang H., Giangrande P., Sala G., Xu Z., Hua W., Madonna V., Gerada D., Gerada C. Thermal Modeling of Directly-Oil-Cooled Permanent Magnet Synchronous Machine, IEEE Transactions on Industrial Electronics, 2019, DOI 10.1109/TIE.2020.2977559

[18] P. Ponomarev, M. Polikarpova and J. Pyrhönen, Thermal modeling of directly-oil-cooled permanent magnet synchronous machine, 2012. XXth International Conference on Electrical Machines, Marseille, 2012, pp. 1882-1887, doi: 10.1109/ICElMach.2012.6350138.

[19] Christian K., Haumer A., Bäuml T. 2008. Thermal Model and Behavior of a Squirrel-Cage Induction Machine for Traction Applications. IEEE Transactions on Industrial Electronics 55 (10): 3555-65.

[20] Melfi M. J., Evon S., McElveen R. 2009. Induction versus permanent magnet motors," in IEEE Industry Applications Magazine, vol. 15, no. 6, pp. 28-35, November-December 2009

[21] United States Patent, Desbiens, Jean-Philippe; Dextraze, Jean-Philippe; Dubé, François; Dupuis, Danny; Latulipe, Éric, Patent number: US10270315B2. 